\title{
The Gastrointestinal Stimulus to Insulin Release
}

\section{SECRETIN}

\author{
D. J. Chisholm, J. D. Young, and L. Lazarus \\ From The Garvan Institute of Medical Research, St. Vincent's Hospital, \\ Sydney, N.S.W., Australia 2010
}

A в S T R A C T The gastrointestinal stimulus to the release of insulin has been investigated in man by the use of a radioimmunoassay for secretin. Serum secretin levels rose rapidly after the oral ingestion of glucose or protein and preceded the elevation of serum insulin. An intravenous infusion of highly purified secretin caused a release of insulin when the serum secretin levels were within the physiological range.

Infusion of hydrochloric acid into the duodenum caused an elevation of serum secretin and serum insulin levels in normal subjects. A similar response of secretin and insulin was seen after intravenous infusion of pentagastrin even when the acid stimulus to the duodenum was prevented. The latter observation suggests that pentagastrin (and probably gastrin) releases secretin by a direct humoral effect which is later fortified by the arrival of gastric acid in the duodenum.

These studies suggest that secretin participates in the augmentation of insulin release after oral stimuli, and that a rapid sequence of humoral events takes place, gastrin releasing secretin and secretin releasing insulin. Subsequently secretin release would be augmented by a local stimulus in the duodenum and insulin release by the rising level of blood glucose or amino acids.

This humoral system, which could also involve other gastrointestinal hormones, would provide a mechanism for facilitating the release of insulin to coincide with the onset of metabolite absorption.

\section{INTRODUCTION}

A duodenal factor with the ability to alleviate diabetes mellitus was postulated in 1906 (1), but the importance

Dr. Chisholm's present address is Frazer Laboratory, Department of Endocrinology, Royal Victoria Hospital, Montreal, Canada.

Received for publication 27 January 1969 and in revised form 8 April 1969. of gastrointestinal hormones in the release of insulin has only recently gained acceptance. Dupré (2) demonstrated increased utilization of intravenous glucose when preceded by an oral glucose load or accompanied by intravenous secretin; alimentary administration of glucose produced a greater and earlier release of insulin than did glucose given intravenously (3-6); and a similar augmentation of insulin release was seen when intraduodenal administration of an amino acid was compared with an intravenous infusion producing comparable blood amino nitrogen levels (7).

Preparations of the individual gastrointestinal hormones have been assessed for an insulin-releasing action. Secretin, administered intravenously in pure or crude form, has induced insulin release in dogs and humans $(2,8-12)$, and studies with in vitro preparations have also confirmed the ability of secretin to release insulin from the pancreas $(13,14)$. Other gastrointestinal hormones including gastrin, pancreozymin-cholecystokinin, and glucagon when given parenterally have resulted in the elevation of serum insulin levels $(15,16,10,11)$ and, in addition, evidence has been presented for a vagal influence on insulin release $(17,18)$.

There is thus evidence that oral glucose or amino acids provoke a greater release of insulin than similar materials given intravenously, and that the hormones of the upper gastrointestinal tract may act as insulin releasers. The problem is to establish the precise role of each of these hormones in the release of insulin under physiological conditions.

In order to study the role played by secretin in the release of insulin, a radioimmunoassay system (19) was set up for the measurement of secretin in human serum. Initial studies were reported of the response of secretin and insulin to oral glucose or intravenous pentagastrin (20). Further studies have now been carried out on the response to these stimuli and also to oral protein, intravenous secretin, intramuscular betazole, and intraduodenal hydrochloric acid. 


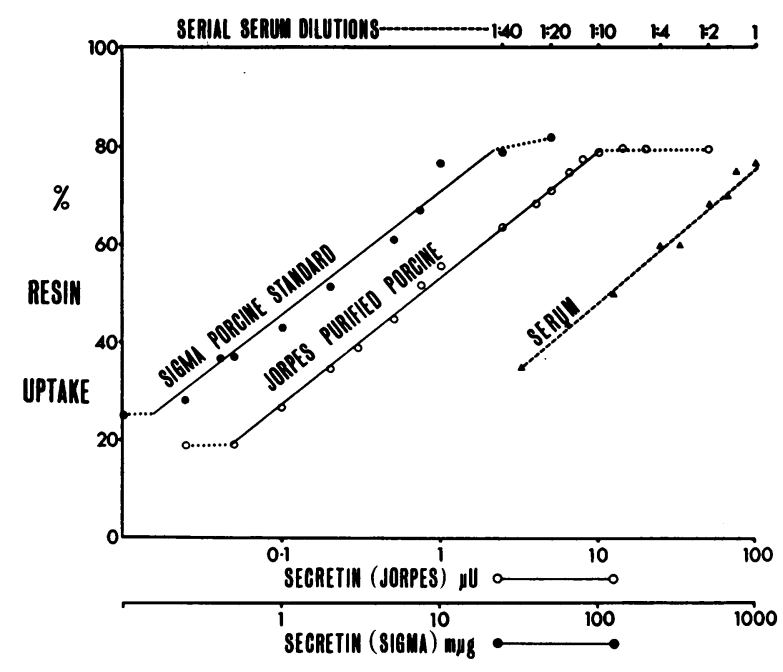

FIGURE 1 Dose-response curves of highly purified (Jorpes) secretin and the standard (Sigma Chemical Co., St. Louis Mo.) porcine secretin dissolved in $3.75 \%$ gelatine compared with serial dilutions of postprandial human serum.

\section{METHOD}

Laboratory methods. Serum secretin levels were measured by a radioimmunoassay method described previously (19). The antiserum to secretin was prepared in rabbits injected with porcine secretin ${ }^{1}$ conjugated to rabbit albumin by the method of Goodfriend, Levine, and Fasman (21). Labeling of synthetic secretin ${ }^{2}$ with ${ }^{125}$ I to a specific activity of 75$100 \mathrm{mc} / \mathrm{mg}$ was accomplished by the method of Greenwood, Hunter and Glover (22). The method was modified by raising the $\mathrm{pH}$ of the initial solution of synthetic secretin to 8.7 by the addition of sodium hydroxide. Attempts at labeling without this modification were unsuccessful. Diffculty in labeling would be anticipated due to the lack of a tyrosine residue in secretin; however, evidence (23) has been advanced that amino acid residues other than tyrosine can be labeled with radioactive iodine, and the labeling of histidine, which is present in secretin, has been proposed. Purification of secretin- ${ }^{125} \mathrm{I}$ was achieved by elution from a G-10 Sephadex column.

The assay system used Amberlite CG-400, type-2 hydroxide cycle anion-exchange resin to separate "free" from antibody-bound secretin- ${ }^{125} \mathrm{I}$ (24). The radioactivity of the resin after washing represented the "free" secretin- ${ }^{125} I$ and was expressed as a percentage of the added tracer (per cent of resin uptake $=\% \mathrm{RU})$. Fig. 1 demonstrates the \% RU after addition to the system of increasing concentrations (plotted logarithmically) of porcine secretin (Sigma Chemical Co.), highly purified secretin, ${ }^{2}$ and of serially diluted postprandial human serum. The dose-response curves are seen to be parallel indicating identical immunological properties.

${ }^{1}$ Biological potency 40 clinical $\mathrm{U} / \mathrm{mg}$; obtained from Sigma Chemical Co., St. Louis, Mo.

${ }_{2}$ Obtained from gastrointestinal hormone (GIH)-Research Unit, Chemistry Department, Karolinska Institute, Stockholm, Sweden.
The \% RU was not altered by the addition to the system of bovine insulin, ${ }^{8} 50-1000 \mu \mathrm{U}$, human growth hormone, $0.5-50 \mathrm{~m} \mu \mathrm{g}$, bovine-porcine pancreatic glucagon, ${ }^{5} 10-100$ $\mathrm{m} \mu \mathrm{g}$, purified pancreozymin-cholecystokinin (CCK), ${ }^{2} 8.3-83$

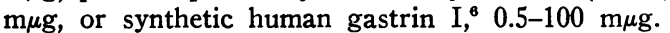

Porcine secretin (Sigma Chemical Co.) of biological potency $40 \mathrm{U} / \mathrm{mg}$ dissolved in $0.5 \mathrm{ml}$ of $3.75 \%$ gelatine was used as the antigen standard, and the results are therefore expressed in millimicrograms of this preparation. The gelatine solution was used to simulate the protein content of serum $(25,26)$ in preference to the use of fasting serum which might contain sufficient endogenous secretin to influence the results at the lower range of sensitivity. Parallel dose-response curves (Fig. 1) were obtained with exogenous secretin in gelatine and serially diluted serum. Also the measurement of secretin levels in $0.5 \mathrm{ml}$ of human serum to which $5-10 \mathrm{~m} \mu \mathrm{g}$ of porcine secretin (Sigma Chemical Co.) had been added was within $15 \%$ of the expected recovery.

The recorded levels of endogenous secretin, although quantitative and satisfactory for comparative studies, are greater than the hormone values which would be reported if the highly purified or synthetic secretin was used as the standard. At the time of these studies, however, the latter preparations were not available in sufficient quantities for use as standards. A comparison between the highly purified secretin of Jorpes (approximately 4000 clinical $\mathrm{U} / \mathrm{mg}$ ) and the Sigma standard (Fig. 1) may be inaccurate due to probable inequality of the biological units (27) but indicates that the immunological potency of the Jorpes purified preparation is about 100 times greater for an equivalent number of biological units in addition to its greater biological potency per unit weight. This fact suggests that the use of the Jorpes purified or synthetic standard might reduce the recorded levels by $10^{-4}$, giving serum levels in the low picogram range.

A significant difference $(P<0.05)$ in \% RU was observed between duplicates of the zero standard and duplicates containing $0.2 \mathrm{~m} \mu \mathrm{g}$ of secretin standard. The assay was therefore sensitive to $0.4 \mathrm{~m} \mu \mathrm{g} / \mathrm{ml}$ when $0.5-\mathrm{ml}$ serum samples were used. Values below this level (which were recorded in most normal fasting subjects) are indicated as zero.

Within-assay precision was tested by 17 estimations, each in duplicate, of two pooled serum samples. Standard deviations of \pm 0.06 and \pm 1.1 were recorded for mean secretin levels of 8.6 and $26.0 \mathrm{~m} \mu \mathrm{g} / \mathrm{ml}$ respectively.

Between-assay reproducibility was tested during seven different assays by the reassay of 64 different serum samples, the interval between assays ranging from 10 to 24 wk. Reassay, after storage at $-10^{\circ} \mathrm{C}$, of 46 samples with a mean level of $7.1 \mathrm{~m} \mu \mathrm{g} / \mathrm{ml}$ (range $0.5-31.0$ ) showed a standard deviation of $1.88 \mathrm{~m} \mu \mathrm{g} / \mathrm{ml}$ estimated by the formula $\mathrm{SD}=$ $\left(\frac{\Sigma \mathrm{d}^{2}}{2 \mathrm{~N}}\right)^{t}(28)$. Elimination of one sample with a large error reduced the standard deviation to $1.15 \mathrm{~m} \mu \mathrm{g} / \mathrm{ml}$. In addition secretin values of $<0.4 \mathrm{~m} \mu \mathrm{g} / \mathrm{ml}$ were reproduced in 14 of 18

\footnotetext{
${ }^{3}$ Mann Research Laboratories, Inc., New York.

4 Biological potency $2.5 \mathrm{IU} / \mathrm{mg}$. Batch No. 62-4 (23) F9. Obtained from Dr. K. Ferguson, Commonwealth Scientific Industrial Research Organisation (CSIRO), Sydney, Australia.

${ }^{5}$ Eli Lilly and Co., Indianapolis, Ind.

- Obtained from Imperial Chemical Industries (ICI), Cheshire, U.K.
} 
TABLE I

Intravenous Infusion of Pure Secretin

\begin{tabular}{|c|c|c|c|c|c|c|c|c|c|c|c|c|c|c|}
\hline \multirow[b]{3}{*}{ Subject } & \multirow[b]{3}{*}{ Assay } & \multicolumn{13}{|c|}{ Time in minutes } \\
\hline & & \multirow[b]{2}{*}{ Basal } & \multirow[b]{2}{*}{2} & \multirow[b]{2}{*}{5} & \multirow[b]{2}{*}{$12 \frac{1}{2}$} & \multirow[b]{2}{*}{20} & \multirow[b]{2}{*}{25} & \multicolumn{7}{|c|}{ Postinfusion } \\
\hline & & & & & & & & $31 \frac{1}{2}$ & $36 \frac{1}{2}$ & 42 & 51 & 60 & 70 & 80 \\
\hline \multirow[t]{4}{*}{ P. F. } & Blood sugar & 80 & & 82 & 80 & 78 & 76 & 84 & 80 & 79 & 75 & 76 & 80 & 80 \\
\hline & Serum secretin & 0 & 23 & 28 & 32 & 35 & 30 & 17 & 6.5 & 3 & 2 & 1.6 & 0.5 & 0 \\
\hline & Serum insulin & 7 & 7 & 15 & 20 & 20 & 18 & 11 & 7 & 7 & 7 & 7 & 7 & 7 \\
\hline & & Basal & 5 & 10 & 15 & 20 & 25 & 30 & 35 & 40 & 50 & 60 & 70 & 80 \\
\hline \multirow[t]{3}{*}{ R. M. } & Blood sugar & 60 & 66 & 65 & 59 & 66 & 64 & 71 & 60 & 63 & 63 & 62 & 58 & 63 \\
\hline & Serum secretin & 0 & 27 & 19 & 17 & 21 & 26 & 9 & 5.6 & 2.4 & 0.8 & 0 & 0 & 0 \\
\hline & Serum insulin & 11 & 13 & 40 & 50 & 51 & 80 & 80 & 64 & 62 & 40 & 40 & 26 & 14 \\
\hline
\end{tabular}

5 clinical $U$ as a loading dose, 1 clinical $\mathrm{U} / \mathrm{min}$ for $25 \mathrm{~min}$; blood sugar, $\mathrm{mg} / 100 \mathrm{ml}$; serum secretin, millimicrograms per milliliter; serum insulin microunits per milliliter.

samples, the mean value of the other four samples being $0.7 \mathrm{~m} \mu \mathrm{g} / \mathrm{ml}$.

Incubation studies were performed on serum samples containing secretin to determine whether enzymatic destruction of secretin in serum (29) would influence the results obtained by this assay method. Secretin levels in samples incubated at $37^{\circ} \mathrm{C}$ for $20 \mathrm{~min}$ or allowed to stand at room temperature for from 4 to $8 \mathrm{hr}$ differed by less than $10 \%$ from samples which had been collected in an ice bath, centrifuged at $4^{\circ} \mathrm{C}$, and immediately stored frozen. We conclude that enzymatic destruction of secretin either is not significant in serum samples or does not alter the immunological activity of secretin and therefore does not influence the results obtained in these studies.

Serum insulin levels were measured by radioimmunoassay by the method of Young and Kraegen (25), but serum immunoreactive glucagon levels are not included in this paper, as interpretation of results would not be valid without data of cross-reactivity with gut glucagon.

Blood sugar was measured by the AutoAnalyzer modification of the Hoffman ferricyanide technique (30).

Experimental procedure. Studies were performed on healthy male students, physicians, or paramedical staff, aged $19-43$, on six subjects with pernicious anemia, and on one with duodenal ulcer. All subjects were fully informed of the nature of the studies. The normal subjects had no close relative with diabetes mellitus and were not more than $15 \%$ above their ideal body weight; they fasted from midnight and the studies were commenced between 8:00 and 9:30 a.m. Intravenous, intraduodenal, and intragastric infusions were administered by a peristaltic constant infusion pump. ${ }^{7}$ Blood samples were collected from a polythene catheter inserted into an antecubital vein at least $30 \mathrm{~min}$ before the commencement of the study and the serum, after separation, was stored at $-10^{\circ} \mathrm{C}$ until assayed.

Intravenous secretin. A highly purified preparation of secretin $^{8}$ was administered intravenously to two normal subjects as a loading dose of $5 \mathrm{U}$, immediately followed by a constant infusion of $\mathrm{I} \mathrm{U} / \mathrm{min}$ over $25 \mathrm{~min}$ (total dose $30 \mathrm{U}$ ).

\footnotetext{
${ }^{7}$ Harvard Apparatus Co., Inc., Dover, Mass., model No. 600-000.

${ }^{8}$ Obtained from GIH Research Unit, Chemistry Department, Karolinska Institute, Stockholm. Potency approximately $4000-5000$ clinical $\mathrm{U} / \mathrm{mg}$.
}

Intraduodenal hydrochloric acid. Hydrochloric acid, a known secretin stimulant, was infused over $30 \mathrm{~min}$ into the duodenum of seven normal subjects and into the stomach of one additional subject. $5-20 \mathrm{mEq}$ of acid in $50-100 \mathrm{ml}$ of distilled water were given via a No. 12 FG Ryles tube positioned under fluoroscopy so that the metal tip of the tube was lying in the third part or distal second part of the duodenum, thereby ensuring that all of the outlet pores lay distal to the pylorus. One subject was given, on separate occasion, $100 \mathrm{ml}$ of isotonic saline (buffered to $\mathrm{pH} \mathrm{7)}$ under identical conditions to assess the possible "mechanical" effects of such an infusion.

Oral glucose. Six normal subjects were given $50 \mathrm{~g}$ of oral glucose after three days on a liberal carbohydrate diet.

Oral protein. Two normal subjects were given a protein meal in the form of $120 \mathrm{~g}$ of cooked lean steak (containing approximately $32 \mathrm{~g}$ dry weight of protein). The steak was presented as small cubes and was eaten, with relish, in less than $3 \mathrm{~min}$.

Intravenous pentagastrin. The effect of gastrin on release of secretin and insulin was studied using pentagastrin, ${ }^{2}$ a pentapeptide containing the active terminal tetrapeptide of gastrin. A continuous intravenous infusion of $0.01 \mu \mathrm{g}$ of pentagastrin $/ \mathrm{kg}$ per min (a submaximal dose) over $15 \mathrm{~min}$ was given to four normal subjects. In order to establish whether the response was caused directly by the pentagastrin or indirectly by the subsequent release of gastric acid an identical infusion of pentagastrin was administered where conditions were modified to prevent an acid stimulus in the duodenum: (a) by continuous gastric aspiration during and for $15 \mathrm{~min}$ after infusion; $(b)$ by intragastric administration of $14 \mathrm{mEq}$ of $0.44 \mathrm{M}$ sodium bicarbonate during the 1 st $10 \mathrm{~min}$ of the infusion preceded by aspiration of the resting gastric contents. (A control study of intragastric sodium bicarbonate produced no secretin or insulin response.); (c) pentagastrin infusion in two subjects with pernicious anemia and achlorhydria.

Intramuscular betazole. Evidence that the action of gastrin may be mediated by histamine $(31,32)$ prompted us to examine the response of secretin and insulin to a histamine equivalent, betazole hydrochloride injection, USP ${ }^{*}$

๑ "Peptavlon," ICI 50, 123. Obtained from ICI, Australia and New Zealand (ANZ), Australia.

Secretin and Insulin Release 

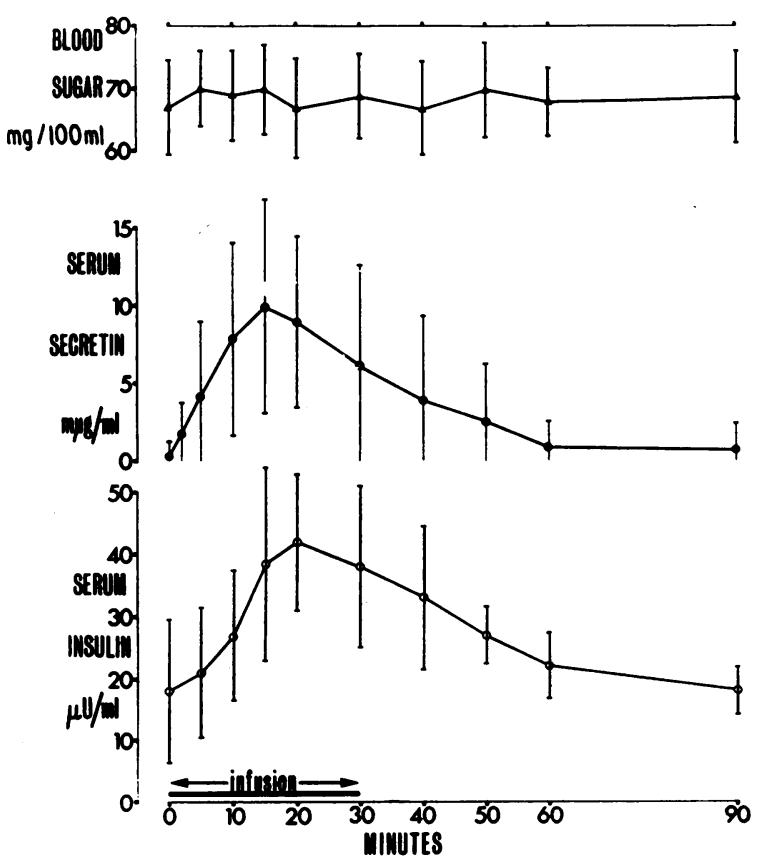

Figure 2 Mean levels \pm SD of blood sugar, serum secretin, and serum insulin in eight normal subjects during and after the intraduodenal infusion of hydrochoric acid for $30 \mathrm{~min}$.

(3-beta-aminoethylpyrazole dihydrochloride), $1.5 \mathrm{mg} / \mathrm{kg}$, by intramuscular injection. One normal subject, one with a duodenal ulcer, and four with achlorhydria (and pernicious anemia) were studied.

Other parenteral studies. $1 \mathrm{mg}$ of glucagon ${ }^{5}$ was given to two normal subjects and $1 \mathrm{~g}$ of tolbutamide ${ }^{10}$ to one normal subject as single intravenous injections.

\section{RESULTS}

Response to intravenous secretin. The serum secretin levels reached maximum values of 27 and $35 \mathrm{~m} \mu \mathrm{g} / \mathrm{ml}$ during the infusion of purified secretin. These serum levels are in the upper range of those recorded in the serum after physiological stimuli (Fig. 3, Table II), a finding indicating that the infusion approximated physiological blood levels. After cessation of the infusion there was a rapid decline in the serum secretin levels, which fell by approximately $75 \%$ in $10 \mathrm{~min}$.

In both subjects there was a significant $(P<0.01)$ rise in serum insulin, in one case to $69 \mu \mathrm{U} / \mathrm{ml}$ and in the other to $13 \mu \mathrm{U} / \mathrm{ml}$ above the basal level.

Blood sugar, serum secretin, and serum insulin levels are recorded in Table I.

Response to intraduodenal hydrochloric acid. Hydrochloric acid, delivered intraduodenally over $30 \mathrm{~min}$, stimulated release of secretin. As there was no evident relationship betwen the amount of acid infused and the

\footnotetext{
${ }^{10}$ Obtained from Hoechst Pharmaceuticals, Melbourne, Australia.
}

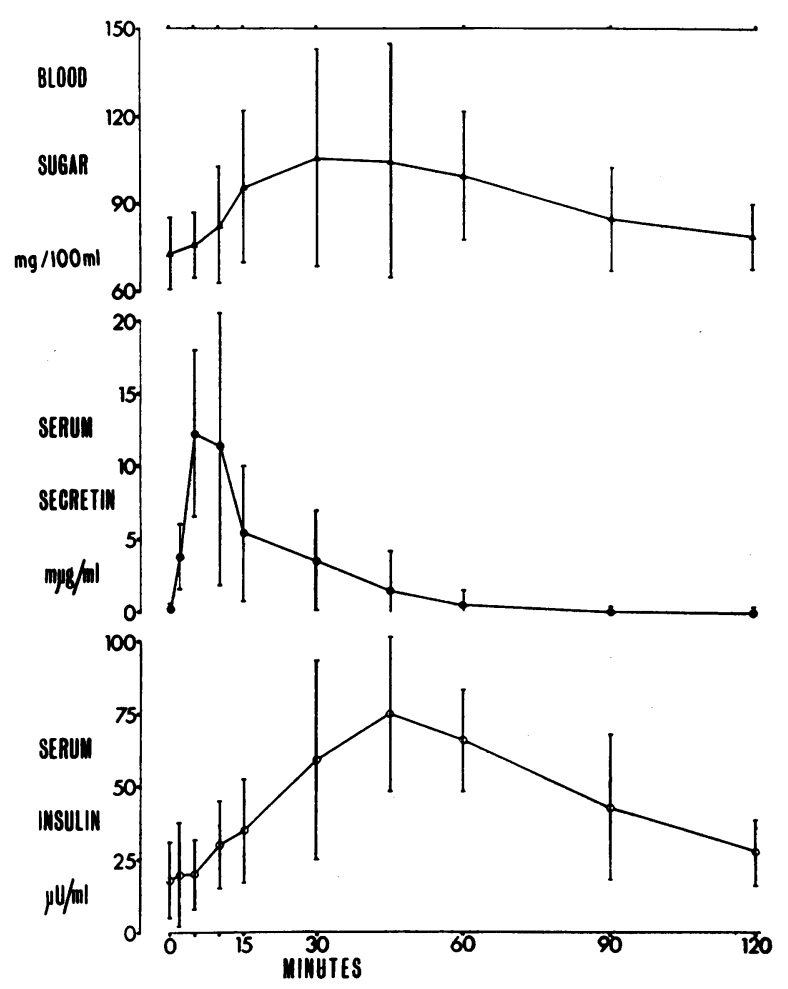

Figure 3 Mean levels \pm SD of blood sugar, serum secretin, and serum insulin in six normal subjects after the oral administration of $50 \mathrm{~g}$ of glucose.

serum secretin or insulin levels recorded, the results are expressed as mean values \pm standard deviations in Fig. 2. Mean secretin levels showed an elevation of $9.5 \mathrm{~m} \mu \mathrm{g} / \mathrm{ml}$ above the mean basal value of $0.45 \mathrm{~m} \mu \mathrm{g} / \mathrm{ml}$, and the maximum level was recorded 15 min after commencing the infusion. Serum insulin levels showed an elevation of $24 \mu \mathrm{U} / \mathrm{ml}$ above the basal value (a significant rise, $P<0.01$ ). The maximum level of serum insulin was recorded 20 min after commencement and closely followed the secretin peak. Blood sugar levels showed no significant alteration.

The infusion of isotonic saline produced no elevation of serum secretin or insulin.

Response to oral glucose. In the six subjects who received $50 \mathrm{~g}$ of glucose a rapid elevation of serum secretin was observed reaching a maximum of 12.2 $\pm 5.7 \mathrm{~m} \mu \mathrm{g} / \mathrm{ml} 5 \mathrm{~min}$ after ingestion (Fig. 3), thus preceding the serum insulin response. The magnitude of the secretin response in the individuals, however, did not relate directly to that of insulin.

Response to oral protein. Two normal subjects showed an early release of secretin after a protein meal $(120 \mathrm{~g}$ of steak), and serum levels of 11 and $20 \mathrm{~m} \mu \mathrm{g} / \mathrm{ml}$ were recorded before a significant elevation in serum insulin levels (Table II). The secretin response in these 
TABLE II

Response to Oral Protein

\begin{tabular}{|c|c|c|c|c|c|c|c|c|c|c|c|}
\hline \multirow[b]{2}{*}{ Subject } & \multirow[b]{2}{*}{ Assay } & \multicolumn{10}{|c|}{ Time in minutes } \\
\hline & & Basal & 2 & 5 & 10 & 15 & 30 & 45 & 60 & 90 & 120 \\
\hline \multirow[t]{3}{*}{ T. H. } & Blood sugar & 70 & & 78 & 75 & 74 & 76 & 77 & 81 & 78 & 73 \\
\hline & Serum secretin & 0 & 0 & 11 & 26 & 23 & 21 & 23 & 14 & 4.5 & 3.6 \\
\hline & Serum insulin & 15 & 16 & 16 & 80 & 100 & 100 & 80 & 38 & 24 & 14 \\
\hline \multirow[t]{3}{*}{ N. S. } & Blood sugar & 54 & & 50 & 50 & 52 & 50 & 54 & 58 & 64 & 64 \\
\hline & Serum secretin & 0 & 0 & 2.8 & 20 & 23 & & 38 & 12 & 5.8 & 5.6 \\
\hline & Serum insulin & 18 & 16 & 16 & 20 & 44 & & 50 & 44 & 30 & 18 \\
\hline
\end{tabular}

Oral protein used, $120 \mathrm{~g}$ of steak; blood sugar, $\mathrm{mg} / 100 \mathrm{ml}$; serum secretin millimicrograms per milliliter; serum insulin, microunits per milliliter.

subjects was of greater magnitude and duration than that seen after oral glucose and was associated with a marked insulin response (maximum elevation 85 and 32 $\mu \mathrm{U} / \mathrm{ml})$.

Response to intravenous pentagastrin. The infusion of pentagastrin in four normal subjects caused a rapid elevation of serum secretin which reached a maximum level of $13 \pm 4.6 \mathrm{~m} \mu \mathrm{g} / \mathrm{ml} 10 \mathrm{~min}$ after the infusion was begun (Fig. 4). After the release of secretin, the mean serum insulin level rose by $31 \mu \mathrm{U} / \mathrm{ml}$ above the basal level, a significant elevation $(P<0.01)$. Blood sugar levels showed a slight, but not significant, fall in the 1 st $10 \mathrm{~min}$.

In the three normal subjects in whom gastric juice was aspirated or neutralized a similar secretin and insulin response was maintained (Table III). This was also true of one achlordydric subject (E.S.), but the other showed only a small secretin response. The serum insulin responses in the subjects with pernicious anemia did not follow the pattern of the normal subjects; in one case (M.F.) there was a prolonged response associated with high fasting blood sugar levels and a high basal level of serum insulin; in the other (E.S.) the serum insulin response was slight.

Response to intramuscular betazole. Two subjects, one normal and one with a duodenal ulcer, showed a marked elevation of serum secretin and insulin levels after an intramuscular injection of betazole (Table IV).

Four further subjects with pernicious anemia were studied with the same dose of betazole and concurrent gastric aspiration. All subjects showed a rise in serum secretin, though the mean maximum level, $3.2 \pm 2.1$ $\mathrm{m} \mu \mathrm{g} / \mathrm{ml}$, was much lower than in the two acid-secreting subjects (maximum levels 17 and $18 \mathrm{~m} \mu \mathrm{g} / \mathrm{ml}$ ). The insulin response of these four subjects was attributable to one subject; the other three had a mean increment of less than $5 \mu \mathrm{U} / \mathrm{ml}$ during the procedure.

Other parenteral studies. No elevation of serum secretin was seen in two normal subjects given $1 \mathrm{mg}$ of glucagon intravenously or in one normal subject given $1 \mathrm{~g}$ of tolbutamide intravenously.

\section{DISCUSSION}

Stimulation of insulin secretion by the parenteral administration of secretin is now well established $(2,8-12)$. It has been argued, however, that this is a pharmacological effect not seen after the physiological release of secretin (14). We have now shown that an infusion of a small amount of purified secretin does cause an increase in serum insulin concentrations when serum secretin levels, determined by radioimmunoassay, correspond to

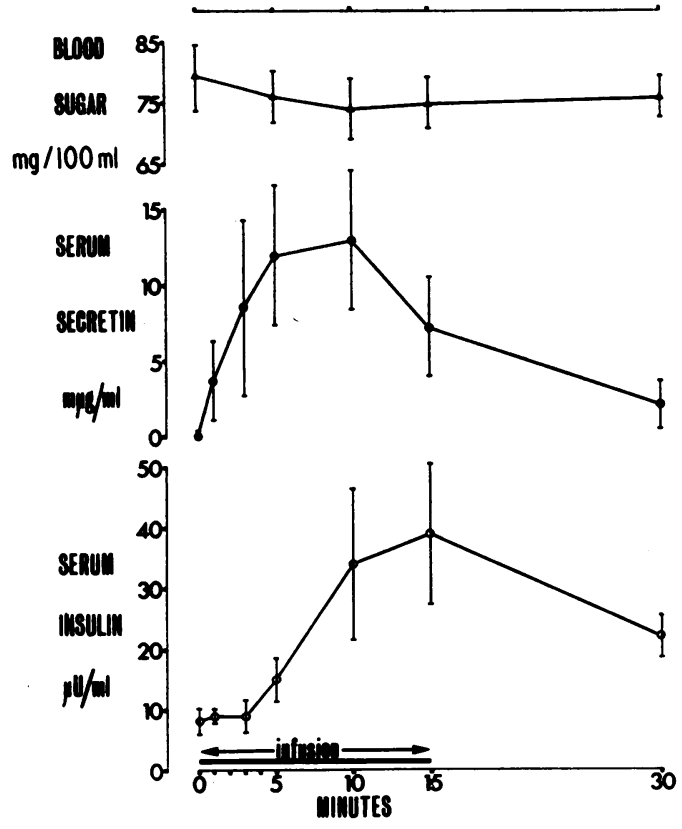

Figure 4 Mean levels \pm sD of blood sugar, serum secretin, and serum insulin in four normal subjects during and after the intravenous infusion of $0.01 \mu \mathrm{g} / \mathrm{kg}$ per min of pentagastrin for $15 \mathrm{~min}$. 
TABLE III

Intravenous Infusion of Pentagastrin

\begin{tabular}{|c|c|c|c|c|c|c|c|c|c|}
\hline \multirow[b]{2}{*}{ Subject } & \multirow[b]{2}{*}{ Gastric interference } & \multirow[b]{2}{*}{ Assay } & \multicolumn{7}{|c|}{ Time in minutes } \\
\hline & & & Basal & 1 & 3 & 5 & 10 & 15 & 30 \\
\hline \multirow[t]{3}{*}{ T. C., normal } & \multirow{3}{*}{$\begin{array}{l}\text { Gastric secretions } \\
\text { aspirated }\end{array}$} & Blood sugar & 64 & & & 63 & & 68 & \\
\hline & & Serum secretin & 0 & & $4^{*}$ & 16 & & 20 & \\
\hline & & Serum insulin & 10 & & $11^{*}$ & 22 & & 51 & \\
\hline \multirow[t]{3}{*}{ R. B., normal } & \multirow{3}{*}{$\begin{array}{l}\text { Gastric secretions } \\
\text { neutralized, } \\
\text { with } \mathrm{NaHCO}_{3}\end{array}$} & Blood sugar & 75 & & & 74 & 72 & 69 & \\
\hline & & Serum secretin & 0 & 0.8 & 4.3 & 4.6 & 1.7 & 0.6 & 0 \\
\hline & & Serum insulin & $\ddagger$ & & & & & & \\
\hline \multirow[t]{3}{*}{ L. M., normal } & \multirow{3}{*}{$\begin{array}{l}\text { Gastric secretions } \\
\text { neutralized } \\
\text { with } \mathrm{NaHCO}_{3}\end{array}$} & Blood sugar & 74 & & & 76 & 72 & 70 & 69 \\
\hline & & Serum secretin & 0 & 12 & 16 & & 17 & 4 & 2.8 \\
\hline & & Serum insulin & 15 & 15 & 15 & 18 & 22 & 35 & 40 \\
\hline \multirow{3}{*}{$\begin{array}{l}\text { M. F., pernicious } \\
\text { anemia }\end{array}$} & \multirow{3}{*}{$\begin{array}{l}\text { Gastric secretions } \\
\text { aspirated, } \\
\text { achlorhydria }\end{array}$} & Blood sugar & 110 & & & 106 & 111 & 112 & 108 \\
\hline & & Serum secretin & 0 & & & 0 & 0.7 & 0.8 & 1.3 \\
\hline & & Serum insulin & 45 & & & 48 & 76 & 86 & 90 \\
\hline \multirow{3}{*}{$\begin{array}{l}\text { E. S., pernicious } \\
\text { anemia }\end{array}$} & \multirow{3}{*}{$\begin{array}{l}\text { Gastric secretions } \\
\text { aspirated, } \\
\text { achlorhydria }\end{array}$} & Blood sugar & 85 & & & 86 & & 92 & 90 \\
\hline & & Serum secretin & 0 & 0 & 11 & 19 & & 4.9 & 1.8 \\
\hline & & Serum insulin & 20 & 20 & 20 & 20 & & 25 & 28 \\
\hline
\end{tabular}

Pentagastrin, $0.01 \mu \mathrm{g} / \mathrm{kg}$ per $\mathrm{min}$ for $15 \mathrm{~min}$; blood sugar, $\mathrm{mg} / 100 \mathrm{ml}$; serum secretin, millimicrograms per milliliter; serum insulin, microunits per milliliter.

* Samples obtained at 2 min.

$\ddagger$ Insufficient serum for insulin assays.

levels recorded after physiological stimuli. Similarly an accepted stimulus to secretin release, i.e. intraduodenal acid, caused the release of insulin immediately after secretin.

The response of normal subjects to oral glucose or protein was characterized by a rapid rise in serum secretin levels which preceded the elevation in serum insulin, although the amount of insulin release was not proportional to the secretin levels. It was noted that the secretin response to the protein meal was of greater magnitude than the response to oral glucose. This observation is in keeping with the known potency of meat in causing gastrin and acid release from the stomach; the acid combines with peptides to provide a strong stimulus to secretin release.

In these oral studies the release of secretin occurred so early that a humoral stimulus to secretin release was suspected. As the release of the hormone gastrin would be expected to precede that of secretin, the effect of gastrin on secretin release was investigated using intravenous pentagastrin. A rapid release of secretin occurred followed by insulin. The same sequence of events occurred even when gastric aspiration or neutralization prevented an acid stimulus in the duodenum. A secretin response to pentagastrin in an achlorhydric patient provided further confirmation of direct secretin release. It thus appears likely that gastrin by a direct humoral ac- tion is an initial stimulus to secretin release, and that this stimulus is subsequently reinforced by the arrival of gastric contents in the duodenum.

As histamine is believed by some workers to mediate the action of gastrin $(31,32)$, a histamine analogue, betazole, was examined for its effect on secretin. Betazole released secretin in one normal subject, one with a duodenal ulcer, and in four patients with achlorhydria. The lower serum secretin levels observed in the latter four subjects suggests that, although histamine has some direct influence on secretin release, its major effect is via gastric acid production.

It can now be seen that after a number of stimuli in normal subjects the release of secretin is closely followed by an insulin response. This, in itself, is not proof that secretin is a principal factor in the insulin release, but the observed insulin respone after intravenous infusion of purified secretin supports this concept. Further, the only insulinogenic factor apparently common to each study is the serum secretin response, and only after oral glucose or protein is there another evident stimulus to insulin release. The possibility remains, however, that other gastrointestinal hormones, such as pancreozymin or "gut glucagon," whose serum levels have not been determined in these situations, could contribute to the $\beta$-cell stimulation. 
TABLE IV

Intramuscular Injection of Betazole

\begin{tabular}{|c|c|c|c|c|c|c|c|c|c|c|}
\hline Subject & Gastric interference & Assay & Basal & 2 & 5 & 10 & 15 & 30 & 45 & 60 \\
\hline D. C., normal & Nil & $\begin{array}{l}\text { Blood sugar } \\
\text { Serum secretin } \\
\text { Serum insulin }\end{array}$ & $\begin{array}{r}74 \\
0 \\
15\end{array}$ & $\begin{array}{l}15^{*} \\
15^{*}\end{array}$ & $\begin{array}{l}16 \\
18\end{array}$ & $\begin{array}{l}76 \\
17 \\
40\end{array}$ & $\begin{array}{l}78 \\
12 \\
45\end{array}$ & $\begin{array}{r}77 \\
8 \\
30\end{array}$ & $\begin{array}{r}80 \\
5\end{array}$ & $\begin{array}{l}77 \\
1.3\end{array}$ \\
\hline $\begin{array}{l}\text { J. M., duo- } \\
\text { denal ulcer }\end{array}$ & $\begin{array}{l}\text { Gastric secretions } \\
\text { aspirated, } \\
\text { partially }\end{array}$ & $\begin{array}{l}\text { Blood sugar } \\
\text { Serum secretin } \\
\text { Serum insulin }\end{array}$ & $\begin{array}{l}74 \\
2.6 \\
20\end{array}$ & & $\begin{array}{l}78 \\
20\end{array}$ & $\begin{array}{l}72 \\
15 \\
25\end{array}$ & $\begin{array}{l}80 \\
18 \\
33\end{array}$ & $\begin{array}{l}78 \\
12 \\
38\end{array}$ & & $\begin{array}{l}82 \\
5.8 \\
27\end{array}$ \\
\hline $\begin{array}{l}\text { Four subjects, } \\
\quad \text { pernicious } \\
\text { anemia }\end{array}$ & $\begin{array}{l}\text { Gastric secretions } \\
\text { aspirated, } \\
\text { achlorhydria }\end{array}$ & $\begin{array}{l}\text { Blood sugar } \\
\text { Serum secretin } \\
\text { Serum insulin }\end{array}$ & $\begin{array}{l}81 \pm 7.8 \\
0.1 \pm 0.37 \\
17 \pm 12.7\end{array}$ & $\begin{array}{r}0.1 \pm 0.37 \\
17 \pm 12.7\end{array}$ & $\begin{array}{l}85 \pm 3.1 \\
1.6 \pm 2.5 \\
17 \pm 12.3\end{array}$ & $\begin{aligned} 88 & \pm 10.5 \\
3.2 & \pm 2.1 \\
21 & \pm 18.3\end{aligned}$ & $\begin{array}{c}89 \pm 15.1 \\
2.7 \pm 1.3 \\
22 \pm 19\end{array}$ & $\begin{aligned} 85 & \pm 12.4 \\
4.4 & \pm 3.8 \\
26 & \pm 26\end{aligned}$ & $\begin{aligned} 93 & \pm 22.4 \\
3.1 & \pm 2.3 \\
26 & \pm 25\end{aligned}$ & $\begin{array}{c}91 \pm 21.5 \\
2.5 \pm 2.4 \\
33 \pm 38\end{array}$ \\
\hline
\end{tabular}

Betazole, $1.5 \mathrm{mg} / \mathrm{kg}$; blood sugar, $\mathrm{mg} / 100 \mathrm{ml}$; serum secretin, millimicrograms per milliliter; serum insulin, microunits per milliliter.

* Serum taken at 3 min.

The failure of intraduodenal acid to produce an insulin response in subjects with pernicious anemia has been used to refute the insulin-releasing role of secretin (33). Our few studies of the response of patients with pernicious anemia to pentagastrin and betazole suggest that insulin release could be deficient in these subjects. Such a defect would not be surprising in view of the association of pernicious anemia with diabetes mellitus (34). The normality of secretin release might also be questioned in view of the proximity of the underlying pathology.

The absence of a fall in blood sugar after significant, though moderate, elevations in serum insulin (Figs. 2, 4; Tables I, III, IV) is difficult to understand. Several explanations could be offered; that compensatory factors prevent hypoglycemia; that the rise in serum insulin does not represent biologically active insulin but an immunoreactive precursor, "proinsulin" (35); or that these small amounts of endogenous insulin do not markedly affect fasting blood sugar levels although they might assist glucose utilization in the presence of hyperglycemia. Our present studies do not answer this problem, but the latter concept would be consistent with evidence summarized by Steele (36) that both hyper-

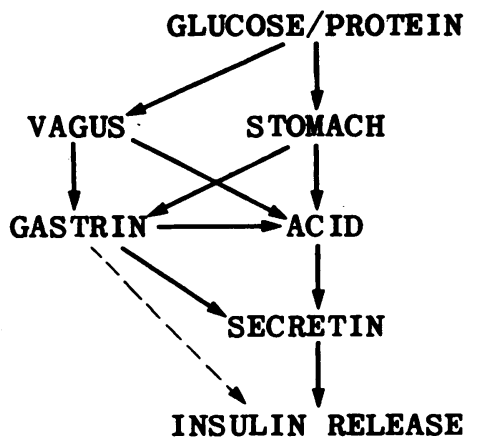

FIGURE 5 A schematic diagram representing the chain of events, including the accepted role of the vagus in gastrin release. glycemia and insulin favor net hepatic glucose uptake. If such be the case a specific function for the gastrointestinal stimulus to early insulin release after oral glucose would be apparent, enabling insulin to coincide with the glucose pulse in the portal vein, so facilitating net hepatic glucose uptake.

In conclusion our studies suggest a chain of events, represented diagramatically in Fig. 5, to include the accepted role of the vagus in gastrin release, which would facilitate the early release of insulin during the onset of metabolite absorption. It is unlikely, however, that the entire gastrointestinal contribution to insulin release is mediated by secretin, and further investigation is still required to elucidate the role of other gastrointestinal hormones. It would also be of interest to know if this system is affected in diabetes mellitus where a specific defect in the early phase of insulin release has been noted $(6,37)$.

\section{ACKNOWLEDGMENTS}

We are indebted to Professor Erik Jorpes and Dr. Victor Mutt of the Karolinska Institute, Stockholm, and to Dr. M. A. Ondetti of the Squibb Institute for Medical Research, New Brunswick, N. J., for their generosity in supplying synthetic secretin which was used in the radioimmunoassay; to Professor Jorpes for further supplies of purified preparations of secretin used in the clinical studies; to Imperial Chemical Industries (Australia and New Zealand), Australia, for supplies of pentagastrin (Imperial Chemical Industries 50123); and to Dr. K. Ferguson, Commonwealth Scientific Industrial Research Organization, Sydney, for the human growth hormone preparation.

\section{REFERENCES}

1. Moore, B., E. S. Edie, and J. H. Abram. 1906. On the treatment of diabetes mellitus by acid extract of duodenal mucous membrane. Biochem. J. 1: 28.

2. Dupré, J. 1964. An intestinal hormone affecting glucose disposal in man. Lancet. 2: 672.

3. McIntyre, N., C. D. Holdsworth, and D. S. Turner, 1964. New interpretation of oral glucose tolerance. Lancet. 2: 20. 
4. McIntyre, N., C. D. Holdsworth, and D. S. Turner. 1965. Intestinal factors in the control of insulin secretion. J. Clin. Endocrinol. Metab. 25: 1317.

5. Elrick, H., L. Stimmler, C. J. Hlad, Jr., and Y. Arai. 1964. Plasma insulin response to oral and intravenous glucose administration. J. Clin. Endocrinol. Metab. 24: 1076.

6. Perley, M. J., and D. M. Kipnis. 1967. Plasma insulin responses to oral and intravenous glucose: studies in normal and diabetic subjects. J. Clin. Invest. 46: 1954.

7. Dupré, J., J. D. Curtis, R. W. Waddell, and J. C. Beck. 1969. Alimentary factors in the endocrine response to administration of arginine in man. Lancet. 2: 28.

8. Dupré, J., L. Rojas, J. J. White, R. H. Unger, and J. C. Beck. 1966. Effects of secretin on insulin and glucagon in portal and peripheral blood in man. Lancet. 2 : 26.

9. Unger, R. H., H. Ketterer, A. Eisentraut, and J. Dupré. 1966. Effect of secretin on insulin secretion. Lancet. 2: 24.

10. Unger, R. H., H. Ketterer, J. Dupré, and A. M. Eisentraut. 1967. Effects of secretin, pancreozymin, and gastrin on insulin and glucagon secretion in anaesthetised dogs. J. Clin. Invest. 46: 630.

11. Jorpes, E., and V. Mutt. 1967. Secretin and glucagon as insulin releasing factors. 1967. Nord. Med. 77: 301.

12. Deckert, T. 1968. Stimulation of insulin secretion by glucagon and secretin. Acta Endocrinol. 57: 578.

13. Pfeiffer, E. F., M. Telib, J. Ammon, F. Melani, and H. Ditschuneit. 1965. Direkte stimulierung der insulinsekretion in vitro durch sekretin. Deut. Med. Wochenschr. 90: 1663.

14. Boyns, D. R., R. J. Jarrett, and H. Keen. 1967. Intestinal hormones and plasma insulin: an insulinotropic action of secretin. Brit. Med. J. 2: 676.

15. Samols, E., G. Marri, and V. Marks. 1965. Promotion of insulin secretion by glucagon. Lancet. 2: 415.

16. Meade, R. C., H. A. Kneubuhler, W. J. Schulte, and J. J. Barboriak. 1967. Stimulation of insulin secretion by pancreozymin. Diabetes. 16: 141.

17. Frohman, L. A., E. Z. Ezdinli, and R. Javid. 1967. Effect of vagotomy and vagal stimulation on insulin secretion. Diabetes. 16: 443.

18. Nelson, J. K., I. S. Mackay, B. Sheridan. 1968. The effect of atropine on the insulin response to glucose in normal subjects. Excerpta Med. Int. Congr. Ser. No. 157, 215.

19. Young, J. D., L. Lazarus, D. J. Chisholm, and F. F. V. Atkinson. 1968. Radioimmunoassay of secretin in human serum. J. Nucl. Med. 9: 641 .
20. Young, J. D., L. Lazarus, E. W. Kraegen, and C. Eastman. 1968. Insulin release following oral glucose. $E x$ erpta Med. Int. Congr. Ser. No. 157. 151.

21. Goodfriend, T. L., L. Levine, and G. D. Fasman. 1964. Antibodies to bradykinin and angiotensin: a use of carbodiimides in immunology. Science. 144: 1344.

22. Greenwood, F. C., W. M. Hunter, and J. S. Glover. 1963. The preparation of ${ }^{181}$ I-labelled human growth hormone of high specific radioactivity. Biochem. J. 89: 114.

23. Izzo, J. L., A. Roncone, M. J. Izzo, and W. F. Bale. 1964. Relationship between degree of iodination of insulin and its biological, electrophoretic and immunochemical properties. J. Biol. Chem. 239: 3749.

24. Lazarus, L., and J. D. Young. 1966. Radioimmunoassay of human growth hormone using ion exchange resin. J. Clin. Endocrinol. Metab. 26: 213.

25. Young, J. D., and E. W. Kraegen. 1968. Simultaneous assay of insulin and glucagon in serum. Aust. J. Exp. Biol. Med. Sci. 46: 697.

26. Bassett, J. M., and A. L. C. Wallace. 1966. Diluents for insulin standards in immunoasay of insulin in undiluted ovine plasma by a double antibody technique. J. Endocrinol. 36: 99.

27. Heatley, N. G. 1968. The assay of secretin in the rat. J. Clin. Endocrinol. Metab. 26: 213.

28. Snedecor, G. W. 1952. Query No. 92. Biometrics. 8: 85.

29. Greengard, H., I. F. Stein, Jr., and A. C. Ivy. 1941. Secretinase in blood serum. Amer. J. Physiol. 133: 121.

30. Hoffman, W. S. 1937. A rapid photoelectric method for the determination of glucose in blood and urine. J. Biol. Chem. 120: 51.

31. Thayer, W. R., Jr., and H. F. Martin. 1967. Histidine decarboxylase inhibition and gastric secretion. Amer. J. Dig. Dis. 12: 1050.

32. Caridis, D. T., J. F. Porter, and G. Smith. 1968. Detection of histamine in venous blood from the stomach during acid secretion evoked by intravenous pentagastrin. Lancet. 1: 1281.

33. Mahler, R. J., and H. Weisberg. 1968. Failure of endogenous stimulation of secretin and pancreozymin release to influence serum insulin. Lancet. 1: 448.

34. Sundberg, A., and A. Gronberg. 1960. Diabetes mellitus and pernicious anaemia. Acta Med. Scand. 166: 147.

35. Rubenstein, A. H., S. Cho, and D. F. Steiner. 1968. Evidence for proinsulin in human urine and serum. Lancet. 1: 1353.

36. Steele, R. 1966. The influences of insulin on the hepatic metabolism of glucose. Ergeb. Physiol. 57: 91.

37. Cerasi, E., and R. Luft. 1967. "What is inherited, what is added" hypothesis for the pathogenesis of diabetes mellitus. Diabetes. 16: 615. 